\title{
Dietmar Rothermund
}

\section{Currencies, Taxes and Credit Asian Peasants in the Great Depression, 1930-1939}

\section{Introduction}

The Asian peasants would not have been affected by the Great Depression if they had been subsistence agriculturists with only minimal relations with the market. In fact, food production rather than the production of cashcrops was predominant in most Asian countries. But even the producers of wheat, rice and millets and other food crops were tied to market forces because they had to pay land revenue and other taxes, or they had to pay rent to landlords and interests to moneylenders. Many of them had become enmeshed in rural credit networks once and for all, because their creditors were eager to keep them in debt by charging high nominal interest rates, while resting content with lower effective interest rates adjusted to the living conditions of their debtors. After all, the peasant had to stay alive in order to serve his creditor.

The burden of rent or revenue had contributed to peasant indebtedness. Moneylenders were usually willing to help the peasant when the collectors of rent or revenue approached them in order to obtain possession of their land in terms of mortgages or by pre-empting their harvest in this way. Moneylenders were usually also graindealers and often financed forward trading. Some of them may have been able to conduct their business purely with their own funds. But most of them had to re-finance their operations through banks or wholesalers etc. Thus the rural credit network was interlinked with higher levels of credit management.

Governments which depended on revenue income were usually glad to rely on these credit networks, because they could be sure of collecting their revenue, as both peasants and moneylenders were eager to protect the land against compulsory sale for arrears of revenue. Moreover, the combined squeeze of revenue demand and debt service ensured that peasants would produce for the market and thus support the cities and yield an export surplus.

This system of linkages was influenced by the behaviour of currency in circulation. The velocity of circulation was slow under rural conditions and the money supply had to adjust to this. Peasants tended to distrust paper money and rather liked to handle coins. The governments concerned therefore had to see to it that 
such coins would be readily available. Thus, their monetary policy was affected by the relative prices of the respective metals in the world market. In conducting their monetary policy their best hope was for a mild inflation. An increase in inflation would reduce the burden of debt of the peasants but also curtail the revenue income of the government in real terms. Deflation could damage the credit system and thus impair revenue income in a different way.

Currencies, taxes and credit were thus interrelated in most Asian countries in a complex system which could be affected by the forces of the world market. The impact of the Great Depression showed this in a dramatic way. The American stock market crash of October 1929 did not affect Asia directly, but precipitated the credit contraction which soon led to a decline of the prices of agricultural produce. Cotton and wheat prices were the first to be affected. But it was only in 1930 that Asia was drawn into the vortex of the depression and therefore we shall begin our account by taking this date as a point of departure. It would be impossible to cover all Asian countries in this paper. Therefore we may present only a few case studies which highlight the complexities mentioned above and also provide studies in contrast. We shall begin with British India and China, which had very different currencies and whose peasants were subjected to different regimes of rent and revenue. A special section will be devoted to Burma which was then still a part of British India. French Indo-China, the Netherlands Indies (Indonesia) and the Philippines will be briefly compared and finally we shall turn to Japan, which experienced the depression in a rather special way as it returned to the gold standard at a most inopportune moment in 1930 and then devalued its currency in 1932 so drastically that it became a champion in the game of competitive devaluation or "exchange dumping" in which many countries at that time participated.

\section{British India: The Overvalued Rupee, Peasant Indebtedness and Nationalism}

India had been on a silver standard up to 1893 and this had shielded the prices of Indian produce against the fall of agrarian prices (in gold) during the depression of the late 19th century. The gradual depreciation of silver after 1876 had contributed to a slow but steady rise in Indian prices. At the same time India had absorbed a great deal of silver and had thus prevented a steeper fall in its world market price. British silver traders profited from this and they wanted the Indian mints to be kept open for the free minting of silver Rupees. But the Government of India was caught in a dilemma as it had to pay its "Home Charges" in gold and could not increase its revenue income in silver. Therefore the mints were closed in 1893 and the Rupee became a token currency pegged to the Pound at $1 \mathrm{~s} 4 \mathrm{~d}$ (Rothermund, 1970: 351-367). The Secretary of State for India had to manage this currency. He had reserves at his disposal for this purpose. Keynes praised this "gold exchange standard" in his first book "Indian Currency and Finance" (1913). But it was not 
as easy to manage as he had thought at that time. The rise of the silver price during the First World War in which India once more absorbed huge amounts of silver forced the Secretary of State to adjust the exchange rate upwards as the silver content of the Rupee surpassed its nominal value. If he had not adjusted the rate, the Rupees would have been withdrawn from circulation and been melted down.

After the war the Rupee declined once more, but now the Secretary of State tried to support it by buying Rupees. He soon exhausted his reserves and thus he had to adopt a different stratagem. Used Rupees returned to the government were not replaced. No new silver Rupees were minted after 1922, nor was paper money issued to the extent that coins were withdrawn from circulation. The silver saved by the government was sold in the world market, thus depressing the silver price. The Rupee was not affected by this as it was a token currency managed by the Secretary of State whose deflationary policy succeeded in stabilising it at $1 \mathrm{~s} 6 \mathrm{~d}$ in 1927. The Currency Act of that year pegged the Rupee to the gold standard at that rate which was 12.5 per cent above the pre-war rate of $1 \mathrm{~s} 4 \mathrm{~d}$ (Rothermund, 1992: 34). No other currency returned to the gold standard above the pre-war parity and the French demonstrated in 1928 that they could do so at one fifth of it (Rothermund, 1996: 70). But by that time India was stuck with a highly overvalued currency. For India's indebted peasants this meant an appreciation of their debts and an increasingly burdensome debt service. When the depression hit them, their incomes were halved, but debt service and the rent or revenue demands remained at the previous level. The government continued its deflationary policy with a vengeance so as to defend the exchange rate and to prevent a "Flight from the Rupee" which hung like a Sword of Damocles over the head of the British government, which feared that a bankruptcy of British India would immediately affect London as well. The Government of India was accordingly instructed to defend the overvalued Rupee (Rothermund, 1992: 41).

The Indian peasant was not only "depressed" by this deflationary policy, but also by the inflexibility of the rent and revenue demand. An economist used to the term "rent" in the context of capitalist agriculture would presume that this is a market price charged by the landlord for the use of his land by a freely contracting "farmer" who would cancel the contract if the price of his produce did not justify the amount of rent to be paid by him. Under such conditions rent charges would have had to be adjusted to the steep fall of prices. But in India "rent" was not determined by the market but by the government, because it was nothing but land revenue in a different guise. In most parts of Southern India, the government had eliminated "landlords" and collected revenue from the peasants who were considered to be "government tenants". In Northern India "landlords" paid the revenue and collected "rent" from the peasant. Originally the respective revenue system had been based on the theory that the government could claim half of the "net rental assets", but, as the government had never been able to establish a proper method of determining such "rental assets", it had simply turned the theory upside down and had empowered the settlement officer to fix the rent, half of which could then be retained by the landlord (Rothermund, 1978: 127). Settlements were 
normally fixed for thirty years and based on the averages of the prices of the preceding ten years. Since these calculations were supposedly based on "scientific standards", no allowances were normally made for bad harvests or other calamities, because these were supposed to be taken care of by the decennial averages. The reaction of the revenue authorities to the impact of the depression was predictable: a fall in prices, even if it was steep and sudden, did not justify any remissions of revenue. It took some time before the depth and persistence of the depression became apparent to the government, but then it was also faced with a dwindling of income from other sources and could not afford to be generous. Even the onerous salt tax which Mahatma Gandhi had made the target of his famous civil disobedience campaign in April 1930 was increased in subsequent years - not to spite him, but simply because the government desperately needed the money (Rothermund, 1992: 109).

When Gandhi had started his campaign he had not at all thought of the depression. Actually the fall in the wheat price affected India only in the summer of 1930 and then many of the peasants of the wheat growing tracts of Northern India provided added momentum to Gandhi's campaign by embarking on a no-rent campaign. For reasons explained above, the landlords were not inclined to remit rents as they themselves had to pay revenue. Furthermore, most of them were also indebted to moneylenders and had to bear the burden of debt service.

In previous years when economic conditions had been favourable, the moneylenders had lent freely to lords and peasants alike. The British laws introduced into India protected creditors fully. If the debtor was recalcitrant and did not appear in a court of law, the judge would grant an ex-parte decree to the moneylender which he could use to extort more from his debtor (Rothermund, 1978: 17). The relationship between creditor and debtor would normally last for a lifetime, because the moneylender saw to it that the peasant would never be able to redeem his debt and would thus provide him with a constant source of income. Moreover, most moneylenders were also merchants and could use their position to dictate terms to the peasant when buying up his produce. The moneylender refinanced his own credit operations with the help of larger graindealers who maintained storehouses. Such full storehouses would serve as collateral for getting loans from banks at fairly low interest rates whereas the rates charged lower down the line were often "usurious".

The depression put this whole system into reverse gear. The banks stopped providing credit for agricultural produce, the wholesalers emptied their storehouses in panic sales and, of course, did not refinance the moneylenders. Those then pounced on their debtors, asking them to pay up. This they could only do by selling land or gold. It is remarkable that Indian land prices only stagnated but did not fall in the depression years, showing that land continued to be regarded as a valuable asset. Gold was available to the peasant mostly in terms of his wife's ornaments. A man who sold his wife's ornaments lost his honour and therefore he would never force her to part with them. But if the only alternative was to sell the family's land she would herself offer her ornaments. The moneylender would 
carry them off triumphantly because he would get a good price for them, particularly after the price of gold increased by about 30 per cent when Great Britain abandoned the gold standard in September 1931.

The British authorities witnessed the stream of gold which poured out of India with great relief, because this unexpected boon saved their exchange rate policy, provided India with the necessary export surplus, and gave a boost to the newly created Sterling area. An independent Government of India could have imposed a gold export embargo and reflated the economy, but the British Indian government and - even more so - the Secretary of State for India were pleased with this result of their deflationary policy which squeezed the gold out of India and helped to support the overvalued Rupee (Rothermund, 1992: 47 f.).

Because no attempt was made to reflate the economy, the depression lingered on in India until the Second World War led once more to an increase in prices. The peasantry resented its fate and turned against the British and towards the Indian National Congress. This was shown by the results of the elections of 1936/37. In preparation for a wider franchise for these elections the Government of India had seen to it that all substantial peasants (as defined in terms of property qualifications) would be able to vote (Rothermund, 1992: 223). There was a hope that these peasants would vote for pro-British agrarian parties. They had earlier not been touched very much by nationalist politics which were mostly urban-based. The depression had changed all this.

Interestingly enough, the moneylenders also flocked to the Congress, because they felt as much betrayed by the British as did the peasants. The law which protected the creditor had been so much taken for granted by the moneylenders that they were surprised when the British tried to impose all kinds of regulations to control rural credit, grant moratoria to indebted peasants, establish debt settlement boards etc.(Rothermund, 1992: 124-127). The nationalists could pick up all these dissatisfied elements and enlist them in the freedom struggle. The British authorities watched with alarm and tried to avoid all steps which might further aggravate rural discontent. The land revenue system was sacrificed for this reason and it did not recover. It was geared to a steady price increase but could not cope with a sudden fall in prices. So-called "revision settlements", which became due after 1930, were quietly shelved as the revenue authorities did not want to instigate political turmoil and also did not know how to fix new decennial averages under the prevailing conditions (Rothermund, 1992: 234f.).

\section{Burma: The Rice Export Economy, Taxation and Peasant Rebellion}

Burma, which remained a part of British India until 1936, was operating under similar conditions as described above, but its economy and its revenue system had some special features which aggravated the depression. Here we shall only deal 
with Lower Burma, which was the centre of a highly productive rice export economy. The fertile Burma Delta was a vulnerable monocrop region which had been reclaimed only under British rule (Adas, 1974: 58-82). The Burmese peasants who had migrated into this area participated in a modern export economy geared to the world market, but they continued their traditional methods of cultivation and remained attached to Buddhism. However, Buddhist institutions in the newly reclaimed Delta were not as strong as in the regions which the migrants had left. The Delta peasants were thus prone to articulate their cultural identity in new associations such as Wunthanu Athin (Own Race Association) which defended the interests of the "sons of the soil" against increasing Indian immigration (Adas, 1974: 196). The "rice frontier" of this new region was closed by the 1920 s. Horizontal expansion was no longer possible. Land prices rose steeply while yields declined, peasants lost their land to landlords for whom they had to work as tenants. By 1929, 46 per cent of the land in the Delta was let out to tenants (Adas, 1974: 150). The rice export economy of the Delta was financed to a large extent by the firms of Chettiar moneylenders who had migrated to Burma from Tamil Nadu since the 1870s. They provided rural credit of nearly 500 mill. Rupees annually (Adas, 1974: 136). Much of this was channelled through local Burmese moneylenders and rice brokers who often advanced money without interest in order to pre-empt the next harvest. As long as prices were stable, there were no problems with this type of rural credit. But when prices fell, the Chettiars would be blamed. The sources of tension had thus developed before the Depression hit Burma. The Delta was like a tinderbox which could be ignited by a sudden spark.

World rice production far surpassed wheat production, but most of the rice did not enter international trade as it was grown for local consumption. Burma, which exported about 2 mill. $t$ per year, was by far the largest rice exporter. The government profited from this in several ways. Unlike in other provinces of India, all male inhabitants between the ages of 18 and 60 had to pay a capitation (poll) tax of Rs. 5 per year if they were married, while bachelors paid half of this rate (Brown, 1999: 5). This was collected before the rice harvest and most people had to resort to the moneylenders for a loan to pay this tax. The moneylenders lent this amount gladly, because it enabled them to pre-empt the harvest. Some months after the harvest, the land revenue was due. The government also collected a rice export duty. Of course, this was of no concern to the peasants, and the government would see to it that this duty did not impede exports.

Rice prices had remained high until October 1930 when wheat prices had already fallen (Rothermund, 1992: 85). Wheat was no substitute for rice either in production or consumption, and there was no overproduction of rice of the kind which had ruined the world wheat market. Supply and demand remained fairly stable for rice throughout the depression years. But the value of rice declined so steeply that by 1933 rice was cheaper than wheat. This was entirely unprecedented. The story of the decline of the rice price is an extraordinary one. As we shall see when discussing Japan, the decline of the rice price started there in October 1930 and should have remained a domestic affair, because Japan neither ex- 
ported nor imported rice at that time. But the news of this fall by 30 per cent immediately reached Liverpool, which controlled the British import market for rice. The traders there felt that the rice price would now follow the wheat price and accordingly the Liverpool price fell by 50 per cent in November. This news reached Calcutta and Rangoon very quickly and rice prices there fell even more steeply when the winter harvest reached the market (Rothermund, 1992: 86). In anticipation of this, the moneylenders refused to provide loans to the peasants when the capitation tax was due in December. The peasants petitioned the government to suspend this tax for the time being, but the Governor of Burma turned down this request (Brown, 1999: 7).

The Burmese peasants had a charismatic leader, Saya San, who had guided them in this petition campaign. He was close to the Burmese nationalists and had been active in agrarian economic enquiries before. He was well informed, but when the Governor remained adamant, Saya San projected himself as a righteous Buddhist king under whose rule there would be no taxes. The Delta with its fragile social order was ripe for a millenarian movement. The branches of the Wunthanu Athin provided an infrastructure for the rebellion (Adas, 1974: 196). Although Buddhism teaches non-violence, Saya San felt justified in advocating violent resistance. The peasant rebellion led by him lasted for almost two years and the government had a hard time in suppressing it.

From what has been said before about the attitude of the British Indian revenue authorities, it is clear that a similar initial intransigence could be expected in Burma. The authorities in Burma also maintained that Saya San's rebellion had absolutely nothing to do with their policy (Brown, 1999: 7). Nevertheless, when the depression persisted, they did relent to some extent. With regard to the land revenue they could do this more easily in Burma than elsewhere in British India, because in Burma this revenue was assessed annually whereas in other parts of India it was usually fixed for a period of 30 years. However, the remission of about 10 per cent in the revenue year 1931/32 and a similar reduction of the capitation tax did not match the steep decline in the income of the peasants and their loss of access to credit. Tensions between peasants and moneylenders were very acute in Lower Burma. As we have seen, rural credit was controlled by Chettiars who were regarded as rapacious strangers. In the areas affected by the rebellion, the Chettiars fled and credit dried up almost completely.

With no credit forthcoming the revenue authorities found it difficult to collect the revenue. In several districts the amounts on which peasants defaulted were quite substantial (about 10 to 15 per cent of the revenue demand) (Brown, 1999: 10-12). In normal times the law of land sale enabled the revenue authorities to auction the land of revenue defaulters immediately. But with a rebellion and with the Chettiars in flight, the government found it hard to proceed in this manner. It seems that in the years after the rebellion had been suppressed, the revenue authorities were able to recover lost ground although the prices remained depressed and the revenue remissions were not very generous. The depression greatly enhanced the alienation of land. Whereas only 31 per cent of land in the Delta was 
held by non-agriculturists in 1929, their share had increased to 50 per cent in 1934 (Adas, 1974: 188).

It should be stressed that the depression led to a loss of the value of the rice crop, but not to an immediate decline in the volume of exports. This implies that initially there was no glut in the Burmese rice market which could be blamed for the drastic fall of rice prices. In 1931 rice exports from Lower Burma remained at the pre-depression level ( 2 mill t .). They then declined to 1.6 mill $t$ in 1932 and 1.4 mill $t$ in 1933. In 1930 the value of rice exports stood at 220 mill. Rs, in 1933, when both volume and value had declined, it amounted to 90 mill. Rs only. By 1933 declining demand clearly affected the price level and depressed the price of rice even below that of wheat. In that year the other great rice economy, China, was also hit by the depression after having escaped its impact in 1931 and 1932.

\section{China: The Silver Currency, Delayed Depression and Rural Misery}

China experienced the depression in a very strange way because of its peculiar currency arrangements. While almost all other countries - by 1930 even the Japanese neighbours - had returned to the gold standard, China had retained its silver standard. The gold/silver ratio which in the 19th century had been $1 / 15$ for a very long time stood at $1 / 35$ in 1928; it amounted to $1 / 54$ by 1930 and in 1931 to $1 / 71$ (Bao-Seing Liao, 1939: 71). The silver price had fallen to the same extent as the prices of commodities such as wheat. This automatic devaluation shielded China against the impact of the depression, but the decline of the silver price also triggered off another surprising development: Chinese overseas who lived in gold standard countries converted their savings into silver and sent it to China where it fuelled an enormous boom at the same time as the rest of the world reeled under the impact of the depression (Remer, 1933: 185). Most of this money was invested in industry which benefited from a measure introduced by the Kuomintang government in 1930 for purely fiscal reasons but then turned out to be the equivalent of a protective tariff. The government relied on customs duties as a major source of its revenue income and decided to assess these duties in gold rather than in depreciating silver (Bao-Seing Liao, 1939: 96). This greatly encouraged the growth of an import substituting industry.

The stream of the savings of overseas Chinese which poured into China in the late 1920s stopped suddenly in September 1931 when the British abandoned the gold standard and silver became much more expensive in terms of British Pounds. By 1932 silver started flowing out of China, initally only in a small way, but to an ever increasing extent in subsequent years (Bao-Seing Liao, 1939: 80).

The Chinese peasants were scarcely affected by this boom, but at least they were protected against the fall of prices of agricultural produce by the inflow of depreciating silver. However, it soon became apparent that for them the depres- 
sion was only delayed. The deflation caused by the outflow of silver depressed agricultural prices in 1933. Rice prices in the Yangzi Delta had averaged about 11 silver taels per shi from 1926 to 1929 . In 1930 they had increased to 13 taels, in the subsequent two years they remained at about 9 taels, dropping to 6 taels in 1933 (Yeh-Chien Wang, 1992: 47).

The fate of the Chinese economy was sealed when the silver mining interests in the USA prevailed upon President Roosevelt to raise the world silver price through the Silver Purchase Act of June 1934. This act obliged the American government to provide one quarter of the backing for its currency in silver instead of in gold. Initially the amount required for this purpose was modest, and if Roosevelt had succeeded in limiting the purchase to that amount and fixing a reasonable price for it, China would have been able to remain on a silver standard. But more gold flowed into the USA and was absorbed in the currency reserve, and this automatically called for an increase in the amount of silver. Moreover, the silver lobby had seen to it that Roosevelt did not fix a silver purchase price and thus this price skyrocketed. It nearly doubled from February to April 1935 (Ghosh, 1976: 352358). It seems that the silver purchase policy was not made a subject of public debate in America. Except for the silver lobby nobody was interested in it. This is why Roosevelt faced no criticism when he followed the advice of that lobby. The Chinese had no voice in this affair, and their appeals could be neglected.

In 1935 silver was sucked out of China and the country was subjected to a severe deflation. The terms of trade had turned against agriculture throughout the period of boom and depression. The inflationary pressures of the boom period from 1930 to 1932 had led to an increase of the prices of goods bought by the peasants. The prices of those goods were reduced by the severe deflation of 1933, but they were still well above the level of the late 1920s and thus were approximately 60 per cent higher than the prices which the peasants received for their produce (Eastman, 1974: 184). Rural credit in China was mostly provided by traders and landlords who pounced on the poor peasants, whose income had dwindled in the depression of 1933-34. Tenancy prevailed in most parts of China, but rents were mostly paid in terms of a fixed amount of grain. This was better than sharecropping because the tenant could enjoy the increase in the harvest due to improvements made by him. But as the grainrents demanded by the landlords were usually quite high, the tenants could get into trouble when the harvest was bad (Perkins, 1969: 102). They then had to ask for grain credits which had to be repaid at the time of the next harvest. The amount to be returned was usually twice the amount taken as a loan (Durau, 1977: 139, 162). The economic position of the landlords also deteriorated during the depression. Land prices fell almost to the same extent as those of produce. Many landlords hired poor people as minions who helped them to intimidate other poor people (Durau, 1977: 100). Law and order in the countryside deteriorated. The stage was set for the political turmoil which soon engulfed the country and made it an easy prey for Japanese aggression.

Before this happened, the Chinese finance minister, $\mathrm{H}$. H. Kung, made a bold attempt at extracting his country from the abyss in which it had been pushed by 
the American silver purchase policy. He had implored Roosevelt in December 1934 to fix the silver price at 45 cents per ounce (Ghosh, 1976: 355). When this was of no avail, he launched a strategy which was so bold and devious that it is hard to believe that it worked. He drove all Chinese banks into bankruptcy and then subordinated them to the Bank of China. Then he abandoned the silver standard and confiscated and demonetised all silver available in China. For this he needed the support of the British ambassador, who issued a Silver Payments Prohibition Regulation which was binding on the British banks which were not under Kung's jurisdiction. Having achieved all this, Kung could issue a new paper currency and got enough notes printed so as to reflate the economy (Bao-Seing Liao, 1939: 125). Whether this would have led to a proper revival of the depressed Chinese economy is difficult to judge, because the Japanese invasion soon subjected China to wartime conditions even before the Second World War engulfed the rest of the world.

\section{Indonesia: Rural Poverty and 'Agrarian Involution'}

Unlike most other colonial governments, which operated colonial currencies such as the Indian Rupee, the Piaster of Indochina or the Peso of the Philippines, the Dutch had no such currency in the Netherlands Indies, where the guilder circulated in the same way as at home. Moreover, the Dutch were the most faithful adherents to the gold standard, which they left only in 1936. This meant that global price movements were bound to affect the colony immediately, but on the other hand the Dutch did not have to follow a specific deflationary policy like the Government of India which was worried about a "flight from the Rupee". Nevertheless, the Dutch drastically reduced the circulation of the currency in Indonesia. In the period from 1925 to 1929,542 mill. guilders were in circulation, of which 344 mill. were paper money and 183 mill. in silver coins; ten years later the total amount had dwindled to 284 mill. guilders, 117 mill. in paper money and 94 mill. in silver coins. The rest consisted in both periods of about the same amount of copper coins (ca. 14 mill.). The most severe reduction was that of the circulation of silver coins. The reason for this is evident from our discussion of the fate of the Chinese currency. The deflation was accompanied by an outflow of gold from the Netherlands Indies which amounted to 144 mill. guilders in the period from 1931 to 1935 (Boomgaard, 2000: 39). As in India, the peasants had to part with their savings, and the dehoarded gold was not used by the colonial government for reflating the colonial economy, but was permitted to flow from the periphery to the centre.

The pressure on the peasants was not only due to indebtedness but to an increasing revenue demand. "Landrent", as this revenue was called in the Netherlands Indies, was raised by about 60 per cent from 1929 to 1934 while rice prices declined by about 60 per cent in the same period (Boomgaard, 2000: 36). The 
government was obviously forced to fall back on "Landrent", as other sources of income such as customs duties, sales taxes etc. had dried up under the impact of the depression. It is surprising that this did not lead to a peasant rebellion, but Governor General de Jonge, who was in charge from 1931 to 1936, was a tough autocrat who enjoyed the full support of the Dutch government. Nationalist leaders like Sukarno had been arrested even before the depression. They spent the depression years in jail and could not provide leadership to the suffering peasants.

Some local institutions may have helped to tide the peasants over difficult times. There was, for instance, the village paddy bank (desalumbung) which was not affected by price movements as credit and repayment were in kind (Boomgaard, 2000: 51). The operations of these banks continued throughout the depression and even increased. But, of course, they were entirely geared to the rice economy and did not deal with cashcrops, which were both affected by the fall in prices and the dwindling of exports.

The most obvious casualty of the depression in the Netherlands Indies was the Javanese sugar industry. Cane cultivation was concentrated in Central and Eastern Java, where it was grown by peasants on land which would otherwise have been available for rice cultivation. Sugar refineries were processing the crop locally. In the pre-depression period 1928-30 nearly 3 mill. $t$ of refined sugar were produced annually. Most of this was exported. About 200000 hectares were under sugar cane at that time. By 1935 this area had been reduced to 28000 hectares and the production of refined sugar had dwindled to 0.5 mill t. Moreover, the price of sugar had fallen to such an extent that export earnings from sugar in 1935 amounted to only about 10 per cent of those in 1928 (Boomgaard, 1988: 158). Much of the land devoted to sugar had reverted to rice cultivation, but with the low price of rice this was not a very profitable option either. In fact, many peasants turned to subsistence crops such as cassava or sweet potatoes.

The blow to Javanese sugar production was largely the result of the protective tariff on sugar introduced by British India, which used to import large amounts of refined sugar from the Netherlands Indies. India had few refineries at that time and produced mostly brown sugar made and consumed by the peasants. Thus the urban population depended for the most part on imported refined sugar. The protective tariff introduced on April 1, 1932 gave an enormous boost to the Indian sugar industry. Sugar imports declined from 0.5 mill $t$ in 1931 to 0.01 mill $t$ in 1937 while Indian sugar production increased from 0.4 mill $\mathrm{t}$ in 1931 to 1 mill $\mathrm{t}$ in 1937. Investment in sugar mills was the only line of industrial investment which progressed very rapidly in India during the depression years. The number of mills increased from 32 in 1931 to 136 in 1937 (Adarkar, 1941: 197f), whereas in the Netherlands Indies the number of mills receded from 178 in 1931 to 81 in 1937 (Boomgaard, 1988: 158).

Rice was an important element of subsistence agriculture in the Netherlands Indies. Moreover, rice cultivation responds almost to an unlimited extent to additional inputs of labour. Yields can be increased by better watering and terracing and other such measures. In strictly economic terms, there may be a problem to 
what extent additional labour inputs actually produce gains. But if labour is cheap and work-sharing rather than work-shedding is the order of the day, such calculations do not matter and it becomes more important how many people who would otherwise remain unemployed can be absorbed in this way. This is the logic of "agrarian involution", which Clifford Geertz has analysed in a thoughtful study of Java's economic history (Geertz, 1963). It seems that this type of "involution" was encouraged by the depression.

A peculiar feature of Dutch colonialism in Indonesia was the comparative smallness of the metropolitan power in relation to the large size of its empire. This was reflected in the rather limited share of the Dutch in Indonesia's foreign trade. In 1933 Dutch imports from this empire constituted only 19 per cent of total Dutch imports, whereas the corresponding ratios for Great Britain and France were 33 and 89 per cent respectively. The export ratio was even smaller: 12 per cent of Dutch exports were absorbed by the empire as compared to 24 per cent and 67 per cent for British and French exports to their respective colonial empires (Prince, 1989: 208). This meant that the metropolitan connection was of marginal importance for Indonesia. But as far as the "national debt" of Indonesia was concerned, more than 80 per cent were held by Dutch creditors (Prince, 1989: 215). These creditors were opposed to any proposal of debt relief or of separating the colonial currency from the metropolitan one so as to be able to devalue it. In this respect the hardening of colonial control on behalf of metropolitan creditors was as much a feature of Dutch colonialism as of the British and French ones in this period.

\section{Indo-China: The Piaster and the Peasant}

The currency of French Indochina was the Piaster issued by the Banque de L'Indochine. This bank operated almost like a central bank and could conduct its own monetary policy - of course, in the interest of the French rulers. The Piaster was originally a silver currency like the Indian Rupee. It seems that the authorities concerned followed a deflationary policy after 1928, in order to stabilise the Piaster and peg it firmly to the Franc and thus to the gold standard. By 1931 this was achieved and the circulation of the Piaster was further reduced (Brocheux, 2000: 257, 263). This stabilisation was intended to protect French capital in IndoChina rather than benefit the peasants. In 1931, the French government sanctioned a massive loan to the colony amounting to 1.3 billion Franc (ca. 55 mill. US \$), aimed at warding off a bankruptcy of the colony which faced a budgetary deficit at that time. The French government could still afford to be generous, because the impact of the depression hit France only in 1934 when the earlier advantage of having rejoined the gold standard much below the pre-war parity in 1928 had worn off (Rothermund, 1996: 70).

In Indochina the rice price fell by about one half in 1931 and stood at about one third of the 1930 price in 1933 . This was a particularly harsh blow for the Mekong 
rice delta, which the French had made into a rice export area very similar to that of Lower Burma. France also collected a capitation tax, and Chettiar moneylenders were in evidence here as well. The amount of land mortgaged to creditors in the delta region and in neighbouring Cambodia increased very rapidly in the depression years. Land prices were reduced by about 50 per cent in the depression years (Brocheux, 2000: 257). This was in striking contrast with India where land prices remained stable, but it was similar to the fall of land prices in China in 1933.

Unlike in Burma, the volume of rice exports did not decrease substantially. This was largely due to the fact that metropolitan France absorbed a great deal of Indochinese rice exports (Booth, 2000: 314). From 1930 to 1933 about 1 to 1.2 mill. $t$ were exported annually. But as the value of these exports dwindled, the balance of trade deteriorated. At the same time the budget deficit of the government increased until 1934. After France went off the gold standard in 1936, the situation in Indochina became also more tolerable. The Piaster was devalued twice - 1936 and 1937. Debtors could heave a sigh of relief now (Brocheux, 2000: 265). The rice price rose after that and almost reached the 1930 level in 1938 (in Piasters).

An important feature of social change which determined the subsequent fate of the country was the increasing influence of big enterprises and big landlords in the depression years. This was due to the fact that the colonial government bailed them out at that time so as to strengthen its political base. In spite of its budget deficit the colonial government sanctioned in 1932 loans of altogether about 10 mill. Piaster to 355 landlords of one of the delta districts (Brocheux, 2000: 265). The peasants could not expect such consideration, and at the most the government showed some leniency by gradually reducing the capitation tax by about 20 per cent from 1931 to 1936 . One may wonder why there was no peasant rebellion in the Mekong delta similar to that which shook Lower Burma. The explanation for this fact could be that there had been an earlier rebellion - not related to the depression - in Northern Annam in 1930, where peasants had risen in protest against the collection of the capitation tax after a drought had ruined their crops. The colonial rulers had put down this rebellion with a heavy hand, and perhaps this was enough to discourage others. The colonial police was omnipresent and was prepared to punish any offender including peasants who refused to pay the capitation tax (Scott, 1976: 105-113). Peasant insurgency was conspicuous by its absence here as well as in the Netherlands Indies and in the Philippines in the days of the Great Depression.

\section{The Philippines: Benefits of the American Connection}

Compared to tough French colonial rule in Indochina, American rule in the Philippines was rather relaxed. There was a capitation tax here, too. It had been introduced by the Spanish colonial rulers and was then called cedula personal. Under Spanish rule it had contributed about half of the total revenue income (Doeppers, 
2000: 57). The Americans relied more on other taxes such as sales taxes and customs duties, and the capitation tax made up only a quarter of their revenue income in the Philippines. Payment used to be strictly enforced, but in the depression years the authorities allowed about a fifth of the population to default on this tax (Doeppers, 2000: 58). When the first Philippine President, Manuel Quezon, assumed office in 1935, he soon introduced a legislative measure which pardoned those who were in arrears with their capitation tax payments in 1936, and then he abolished this unpopular tax altogether in the following year (Doeppers, 2000: 58). One may argue that the French in Indochina also reduced the capitation tax by about one fifth in the course of the depression years. But this was a very gradual procedure and affected all taxpayers in the same way, while the tolerance of the Philippine administration meant total and immediate relief for the peasants in the regions worst affected by the depression.

The colonial currency, the Peso, was pegged to the Dollar. It had been devalued in 1921, and subsequently a strict currency board system had managed to maintain the peg at 2 Pesos to the Dollar until 1941 (Booth, 2000: 301). The authorities reduced the money supply by about 30 per cent from 1929 to 1932 (Wolters, 2000: 88). Perhaps this was done in order to support the exchange rate, but it may also have been due to the conventional wisdom of this time that money supply should be adjusted to the level of economic activity.

A special benefit which the Philippines could derive from the American connection was access to the American market for its sugar production. This saved the sugar growers of the Philippines from the fate of their Javanese counterparts who had to reduce their output drastically. Sugar export of the Philippines even increased from an average of 0.7 mill. $t$ in the period from 1929-31 to 1 mill. $t$ in 1932-34. Sugar, which had contributed only about one third to total exports in 1929, made up nearly two thirds of them in 1932. More than three quarters of the foreign trade of the Philippines was with the USA at that time, while it had only been one half in 1914. The access to the American market was not quite free, but was regulated by a quota system which privileged the larger sugar mills, many of which were controlled by American companies (Yoshiko Nagano, 1988: 177). Colonial economic integration of the Philippines with the USA was thus enhanced by the depression. Products which did not quite fit into this pattern, such as the famous Manila hemp (abaca), lost much ground during the depression, and the regions producing it (Southern Luzon, Samar, Leyte) were badly affected by it. Under the immediate impact of the depression, hemp production declined by about 50 per cent. There was a recovery in 1934, but another slump in subsequent years. The peasants in the respective regions returned to subsistence agriculture, growing crops like cassava etc. normally regarded as food for the poor. The hemp region had the highest incidence of non-payment of the capitation tax (Doeppers, 2000: 63).

The rice economy of the Central Luzon plains which produced food for internal consumption, but was nevertheless affected by the global fall of the rice price, could not benefit from the US connection either (Wolters, 2000: 102f.). The colo- 
nial administration had introduced a measure, the Bonded Rice Warehouse Law of 1930, which was supposed to support rural credit and free the peasants from their dependence on the credit provided by Chinese rice traders. The licensed warehouse keeper could issue receipts for rice stored by him on behalf of the peasants who could use these receipts as collateral for obtaining loans from banks. This led to a withdrawal of the Chinese from the rural credit market. They had freely lent money to peasants without interest as long as they could pre-empt their rice harvest in this way. The warehouse scheme limited this activity. Moreover, the warehouses were mostly run by local people and not by the Chinese, who were used to buying and selling rice, but not to storing it in large quantities. The legal measure was well-meant, but it reduced the volume of rural credit at a crucial time and probably benefited the richer peasants and landlords who knew how to handle warehouse receipts and bank loans. But colonial governments were normally interested in strengthening their social base among the rural upper strata rather than among the poor. Thus in terms of politics this may have been a very shrewd move.

\section{Japan: 'Beggar-thy-neigbour’ and Exploit Yourself}

Of all the countries of Asia, Japan alone was both economically fairly advanced and politically fully in control of its fate. As a sovereign nation it could conduct is currency policy so as to suit its perceived national interest. But it followed the general craze for the re-establishment of the international gold standard. Great Britain had set a precedent by returning to the gold standard at the pre-war parity in 1925, and the Japanese leaders were not satisfied with less. National prestige more than anything else drove the Japanese to adopt this course (Allen, 1983: 106). The British decision of 1925 , which also proved to be unwise when considered with the benefit of hindsight, could perhaps be explained in terms of the quest of London to recover its position as the world's financial centre, but Japan had no such excuse, and the timing of its return to the gold standard (January 1930) and its adamant defence of the Yen by a severely deflationary policy in the subsequent two years looked like a tragic comedy. Finance Minister Inouye played the role of a latter-day Don Quixote in this drama. He was murdered by army officers for this, and his successor Takahashi, who managed to get Japan out of the depression, eventually met with the same fate, because he resisted re-armament (Allen, 1983: 147).

The Japanese peasantry had all along been the neglected half of the nation and also suffered most under the impact of the depression. Japanese agriculture had been transformed in the nineteenth century. Old feudal ties of dependence had been relinquished under the impact of a modern market economy. Land had become concentrated in the hands of larger landholders, much of it by means of the foreclosure of mortgages. But this had not led to large-scale capitalist farming. Wage labour was expensive and landlords had increasingly let out their lands to 
tenants. Productivity had been enhanced by intensive family labour. Although Japanese industry had absorbed a great deal of labour, the share of the population engaged in agriculture had remained fairly stable at around 50 per cent from 1868 to 1940 (Smith, 1966: 210). The agriculturists were subjected to a land tax which usually amounted to more than 30 percent of the gross produce. Many peasants were indebted to local moneylenders who used their hold over the peasantry so as to control their land by means of mortgages and to appropriate their produce which they marketed at a profit (Smith, 1966: 158-160).

In spite of increases in agricultural productivity the cultivation of rice had in the early twentieth century lagged behind urban demand. After the First World War, the urban underclass had shocked the ruling elite by "rice riots", because the cost of living had risen due to wartime inflation (Allen, 1983: 103). As a reaction to this, the government had encouraged large-scale imports of rice so as to keep the rice price low and the urban underclass contented. This was, of course, of no benefit to the Japanese peasants. Burma, Thailand and Indochina exported rice to Japan in those years. Burmese rice, which was harvested in winter and arrived in Japan in March, was of strategic importance in keeping the rice price down, because in Japan the rice was harvested in October and most of this was consumed by March. However, the Japanese government was interested in attaining national selfsufficiency in this field. This was achieved in 1928 when a rice import embargo was introduced (Rothermund, 1996: 41).

In the meantime many peasants had also discovered another source of income: the breeding of silkworms for the Japanese silk industry which had a good market in the USA. By the late 1920 s about one third of Japanese exports consisted of silk, of which more than 90 per cent was absorbed by rich Americans. The stock market crash of 1929 reduced the demand for silk all of a sudden and the deflationary policy mentioned above raised its export price. Thus from 1929 to October 1930 silk exports shrank by 60 per cent. And as we have mentioned before, the deflationary policy and a good rice harvest led in October 1930 to a fall of the rice price by 30 per cent. In this way the peasantry suffered a severe loss of income both with regard to rice and silk worms. Many peasants had to sell their daughters to brothels or hire them out to the new cotton textile mills which exploited cheap labour (Waswo, 1988: 116f., 123-131).

The Japanese army whose soldiers and young officers mostly came from peasant families now emerged as the moral advocate of the suffering peasantry. But the leaders of that army were more interested in increasing military expenditure than doing anything for the peasants (Allen, 1983: 141f.). By 1934 this expenditure amounted to 942 mill. Yen whereas only a meagre amount of 83 mill. Yen had by that time been spent on rural public works which actually did not benefit the peasants but the construction industry.

When the Yen was allowed to float in 1931 after Japan had followed British precedent in abandoning the gold standard, the Japanese currency almost immediately lost 60 per cent of its previous value and thus made Japanese exports extremely competitive in the world market. Joan Robinson in analysing competitive 
devaluation coined the term "beggar-thy-neighbour" (Rothermund 1996: 6). Another term referring to the same phenomenon is "exchange dumping", meaning that goods are actually sold below the cost price due to a low exchange rate. Both terms focus on the "neighbour" who is affected by this policy. But it should also be noticed that the exporter must exploit himself in order to follow this course. In fact, Japan did exploit itself by flooding the world market with cheap goods so as to earn foreign exchange which was then mainly spent on machinery and armament (Rothermund, 1996: 152f.). The Japanese elite which pursued this policy did not exploit itself, but rather the peasants and other poor people who had to pay the bill. The recovery from the depression was thus not a story of a glorious achievement, but of social injustice. This was defended in terms of the national interest which eventually produced military aggression.

\section{Conclusions}

This survey of several Asian countries has shown that the respective currencies and the monetary policies adopted to support the exchange rate and to prevent the flight of capital were crucial in transmitting the impact of the depression - often with a vengeance. The only exception was China which stuck to its silver standard, but was then caught in a delayed but even more severe depression due to the American silver purchase policy. We have also seen that governments everywhere showed great reluctance to cut taxes so as to relieve the sufferings of the peasantry. First of all, the authorities concerned initially did not see that the depression was more than a passing phenomenon, and once they noticed this, they were caught in a dilemma as other sources of revenue income dwindled and they were thrown back on the most regressive and broadly based taxes which were also most unpopular. Colonial rule thus turned out to be more oppressive at a time when it became practically superfluous. Imperialists had always argued that colonies were required so as to have access to scarce resources. Now that the depression had made all colonial commodities extremely cheap, it was hardly worth spending much on the administration and defence of colonies.

Credit relations were, of course, one good reason for holding on to colonies which were indebted to creditors in the countries at the centre of the world economy. Credit also determined financial relations all the way down to the remotest village. Many debts incurred before the onset of the depression became terribly burdensome under the double impact of deflation and the loss of income due to the steep fall in prices.

With all this, peasant protest might be expected to have been much more widespread than it actually was in the depression years. In fact, peasant solidarity was difficult to establish due to the internal differentiation of the peasantry, the variety of local conditions and the uneven incidence of the demands of the authorities. If credit was available, the peasant would normally rather pay up than defy the tax 
collector. It was only when credit was refused at the very moment when taxes were due that the peasant was caught with his back to the wall. Under such conditions peasant solidarity could suddenly arise, and under a charismatic leader might pose a dramatic challenge to the government. This was a rare constellation and therefore peasant protest in the years of the depression was isolated and hardly articulated at all.

\section{References}

Adarkar, B. P., The Indian Fiscal Policy (Allahabad 1941)

Adas, M., The Burma Delta: Economic Development and Social Change on an Asian Rice Frontier, 1852- 1941 (Madison 1974)

Albert, B. / Graves A. (eds.), The World Sugar Economy in War and Depression, 1914-1940 (London 1988) 157-169

Allen, G. C., A Short Economic History of Japan (London 41983)

Bao-Seing, Liao, Die Bedeutung des Silberproblems für die chinesischen Währungsverhältnisse (Berlin 1939)

Boomgaard, P., Treacherous Cane: The Java Sugar Industry between 1914 and 1940, in: Albert / Graves (eds.), (1988) 157-169

Boomgaard, P. / Brown I. (eds.), Weathering the Storm. The Economies of Southeast Asia in the 1930s Depression (Leiden 2000)

Boomgaard, $P$., Surviving the Slump. Development of Real Income during the Depression of the 1930s in Indonesia, in: Boomgaard / Brown (eds.), (2000) 23-52

Booth, A., Crisis and Response: A Study of Foreign Trade and Exchange Rate Policies in Three South East Asian Colonies in the 1930s, in: Boomgaard / Brown (eds.), (2000) 295320

Brocbeux, P., The state and the 1930s Depression in French Indo-China, in Boomgaard / Brown (eds.), (2000) 251-272

Brown, I. (ed.), The Economies of Africa and Asia in the Inter-war Depression (London 1989)

Brown, I., Material Conditions in Rural Lower Burma during the Economic Crisis of the early 1930s: What the Cotton Textile Import Figures Reveal, in: Boomgaard / Brown (eds.), (2000) 109-120

Brown, I., Tax Remission and Tax Burden in Rural Lower Burma during the Economy Crisis of the early 1930s, in: Modern South Asian Studies 33,2 (1999)

Doeppers, D. F. The Philippines in the Great Depression: A Geography of Pain, in: Boomgaard / Brown (eds.), (2000) 53-82

Dore, R. / Sinha, R.. (eds.), Japan and World Depression. Then and Now (London 1987)

Durau, J., Die Krise der chinesischen Agrarökonomie, in: Lorenz (ed), (1977)

Eastman, L. E., The Abortive Revolution. China under Nationalist Rule, 1927 -1937 (Cambridge, Mass. 1974)

Feuerwerker, A., The Chinese Economy, 1912-1949 (Ann Arbour 1968)

Geertz, C., Agricultural Involution. The Process of Ecological Change in Indonesia (Berkeley 1963)

Gbosh, P. S., Sino-American Economic Relations, in: International Studies 15 (1976)

Lorenz, $R$. (ed.), Umwälzung einer Gesellschaft. Zur Sozialgeschichte einer Revolution, 1911-1949 (Frankfurt 1977)

Maddison, A. / Prince, G. (eds.), Economic Growth in Indonesia, 1820-1940 (Dordrecht 1989)

Perkins, D. D., Agricultural Development in China (Chicago 1969) 
Prince, G., Dutch Economic Policy in Indonesia, 1870-1942, in: Maddison / Prince (eds.), (1989) 203-226

Rawski, T. G. / Li, L. M. (eds.), Chinese History in Economic Perspective (Berkeley 1992)

Remer, C. F., Foreign Investments in China (New York 1933)

Rothermund, D., India's Silver Currency. An Aspect of the Monetary Policy of British Imperialism, in: Indian Economic and Social History Review 7,1 (1970)

Rothermund, D., Government, Landlord and Peasant in India. Agrarian Relations under British Rule, 1865-1935 (Wiesbaden 1978)

Rothermund, D., India in the Great Depression, 1929-1939 (New Delhi 1992)

Rothermund, D., The Global Impact of the Great Depression, 1929-1939 (London 1996)

Scott, J., The Moral Economy of the Peasant: Rebellion and Subsistence in Southeast Asia (New Haven 1976)

Smith, T. C., The Agrarian Origins of Modern Japan (New York 1966)

Waswo, A., Japan's Rural Economy in Crisis, in: Brown (ed.), (1989)

Wolters, W. G., Uneven Impact and Regional Responses: The Philippines in 1930s Depression, in: Boomgaard / Brown (eds.), (2000) 83-108

Yeh-Chien, Wang, Secular Trends of Rice Prices in the Yangzi Delta, 1638-1935, in:, Rawski / Li (eds.), (1992) 35-68

Yosbiko, Nagano, The Oligopolistic Structure of the Philippine Sugar Industry during the Great Depression, in: Albert / Graves (eds.), (1988) 170-181 
